\title{
Thermal stability of lactic acid bacteria metabolites and its application in preservation of tomato pastes
}

\author{
Samuel Temitope Ogunbanwo*, llesanmi Festus Fadahunsi and Anwuli Jennifer Molokwu \\ Department of Microbiology, Faculty of Science, P.O. Box 22346, University of Ibadan, Ibadan, Nigeria. \\ Email: st.ogunbanwo@mail.ui.edu.ng
}

Received 19 May 2013; Received in revised form 9 August 2013; Accepted 16 August 2013

\begin{abstract}
Aims: Tomato (Lycopersicum esculentum) is one of the highly nutritious and perishable food ingredients. This work is intended to apply bio-preservation in extending the shelf life of tomato paste.

Methodology and results: Isolation of lactic acid bacteria (LAB) and spoilage tomato microorganisms was done from healthy and spoilt tomato samples respectively using De Mann Rogosa and Sharpe and nutrient agar and potato dextrose agar respectively. Antimicrobial metabolites of LAB (lactic acid, diacetyl and hydrogen peroxide) were determined and effect of treatment temperatures $\left(60,80\right.$ and $100{ }^{\circ} \mathrm{C}$ for $\left.30 \mathrm{~min}\right)$ on its efficacy was also determined. The results obtained from this study revealed that Lactobacillus brevis and $L$. plantarum were isolated from healthy tomato samples while Bacillus megaterium, B. laterosorum, Pseudomonas syringe, Aspergillus fumigates, Fusarium solani, F. acuminatum and $F$. funjikuroi were isolated from the spoilt tomato samples. LAB isolated produced antimicrobial compounds with $L$. plantarum I recording the highest lactic acid $(2.7 \mathrm{~g} / \mathrm{L})$, diacetyl $(2.2 \mathrm{~g} / \mathrm{L})$ while $2.4 \mathrm{~g} / \mathrm{L}$ of hydrogen peroxide was observed. Metabolite extract from L. brevis I (ML7) exhibited the largest broad spectrum activity with inhibition zones ranging from $10 \mathrm{~mm}$ to $18 \mathrm{~mm}$ against spoilage microorganisms except $F$. funjikuroi. At $60^{\circ} \mathrm{C}$ and $80^{\circ} \mathrm{C}$ metabolites produced by LAB species were inhibitory to some of the tomato spoilage microorganisms and at $100{ }^{\circ} \mathrm{C}$ no inhibition was detected. The shelf life of tomato paste treated with metabolite extracts from L. plantarum I, L. plantarum II, L. brevis I and L. brevis II (LAB3) and kept in refrigerator showed the longest shelf life of 20 days.

Conclusion, significance and impact study: Metabolite extracts from selected LAB were more effective than methyl propylparaben in preserving tomato paste stored at $4{ }^{\circ} \mathrm{C}$ and $25^{\circ} \mathrm{C}$ against spoilage bacteria and the application of biopreservative should be encouraged in food processing industries.
\end{abstract}

Keywords: Lactic acid bacteria, tomato spoilage microorganisms, antimicrobial compounds, biopreservative, shelf life.

\section{INTRODUCTION}

Microbial spoilage of fruits and vegetable is known as rot, which manifests as loss of texture (Soft rot), changes in colour (black or grey) and often off odor (Trias et al., 2008). Tomatoes which is the third most important vegetable crop on the basis of its market value (Law Ogbomo, 2011), coupled with high nutritive status and high water content which makes it very susceptible to spoilage bacteria and fungi during storage, harvesting and transportation (Spadaro and Gullino, 2004).

Fresh produce like fruits and vegetables, are normal part of the human diet and are consumed in large quantities in most countries. These products are rich in carbohydrates and poor in proteins with $\mathrm{pH}$ value from slightly acidic to 7.0 and provide a suitable niche to several bacteria, yeasts and moulds (Wiessinger et al., 2000; Trias et al., 2008). Tomato (Lycopersicum esculentum) is one of the highly nutritious food ingredient used in the preparation of food all over the world (Ogunniyi and Oladejo, 2011). It is a perishable fruit and its production in the world in 2008 was about 130 million tons. In Africa, Nigerian ranks highest in tomato production with about 829,000 tons/annum (Grubben and Denton, 2004). It is considered as the most important vegetable after onions and pepper (Fawusi, 1978). Its utilization as an ingredient in vegetable salads, other dishes and its processing into different products like puree, ketchups and juice is well documented. Nutritionally it contains a large amount of water, niacin, calcium and vitamins especially A, C, E which are important in the metabolic activities of man and protects the body against diseases (Taylor, 1987). Lycopene (acarotene) an essential component of tomato contributes in the prevention of cardiovascular disease and cancer of the prostrate (Clinton, 1998; Bernard et al., 1999). The characteristics flavor of tomato is produced by the complex interaction of the volatiles and non-volatile components (Petro-Turza, 1987; Buttery, 1993). Among the common post-harvest fungal pathogens of tomatoes are Pencillium expansum, Bobytis cinerea, Monilinia laxa and Rhizopus stolinifer (Ogawa et al., 1995; Pla et al., 2005). While that of bacterial origin are Erwinia carotuvora and Xanthoman ascampestrispv and 
Vesicatoria are most common (Pla et al., 2005). In Nigeria, it is estimated that about $40-50 \%$ of tomato are wasted at post-harvest stage every year (Okunoya, 1996; Olayemi et al., 2010).

Antimicrobial agents are compounds used to extend the lag phase or kill microorganisms (Davidson and Harrison, 2002). Only a few naturally occurring antimicrobials, such as nisin, natamycin, lactoferrin and lysozyme have regulatory approval for application in the food industry. In recent times, the understanding of the preservation mechanisms of $L A B$ is being exploited for industrial production of foods (Trias et al., 2008) because of their natural acceptance as GRAS (Generally Recognized as Save) for human consumption and exhibit antimicrobial property (Aguirre and Collins, 1993).

The reported survival of these microorganisms in post-harvest conditions of tomatoes makes them most adequate to be selected as a candidate for the prevention of post-harvest spoilage (Trias et al., 2008). In view of the use of chemical control agents which is of increasing public threat due to their toxicological risk which can cause health problems such as cancer and resistance development by spoilage microorganisms, there is need for an alternative method of preserving tomatoes during the period of abundance in Nigeria.

This work is designed to investigate the effectiveness of lactic acid bacteria metabolites in preserving tomato paste.

\section{MATERIALS AND METHODS}

\section{Sample collection}

Fresh and spoilt tomato samples were purchased from Shasha and Bodija markets in Ibadan, Nigeria. The samples were collected in separate sterile polythene bags and immediately transported to the laboratory for analysis.

\section{Isolation procedure}

The media used for isolation of microorganisms were MRS (De Mann Rogosa and Sharpe), nutrient agar, potato dextrose agar and plate count agar. Three grams of fresh healthy tomato and $3 \mathrm{~g}$ of spoilt tomato samples were separately weighed and differently transferred into sterile pestle containing $10 \mathrm{~mL}$ of sterile distilled water and grinded with mortal to dislodged the microorganism present in the tomato samples. The mixture obtained was serially diluted and $1 \mathrm{~mL}$ of $10^{4}$ dilution was used to inoculate MRS and plate count agar plates. Incubation was carried out anaerobically at $37^{\circ} \mathrm{C}$ for $48 \mathrm{~h}$ and $1 \mathrm{~mL}$ of $10^{4}$ dilution of the mixture obtained from the spoilt tomato sample was used to inoculate nutrient agar, potato dextrose agar and plate count agar plates. Inoculation was carried out at $30{ }^{\circ} \mathrm{C}$ for 7 days for the PDA plates while the other plates were incubated at $30{ }^{\circ} \mathrm{C}$ for $48 \mathrm{~h}$. The plates were later examined for growth of microorganisms which were repeatedly sub cultures to obtain pure cultures which were differently stored on agar slants in MacCanthney bottles.

\section{Identification of isolates}

The pure spoilage fungal isolates were examined Macroscopically and Microscopically and identified with reference to Alexopoulos and Mims (1969) while the characterization of the pure LAB cultures and spoilage bacterial isolates were carried out using API $50 \mathrm{CH}$ strips and $50 \mathrm{CHL}$ medium (API system, Montalieu, Vericeu, France) and API 20E and API 20NE respectively and identified with reference to Bergey's manual of systems bacteriology (Sneath, 1986).

\section{Determination of proximate composition of healthy and spoilt tomato}

The healthy and spoilt tomato samples were subjected to proximate analysis as follows:

\section{Moisture content determination}

The moisture content of the fermented samples was determined by weighing into moisture cans then weighed and then placed in an oven at $80{ }^{\circ} \mathrm{C}$ for $24 \mathrm{~h}$ to dry to a constant weight. Then brought out and allowed to cool in desiccators and then reweighed (A.O.A.C., 1995).

Thus, moisture content $=\frac{\text { initial weight }- \text { final weight }}{\text { Initial weight }} \times 100$

\section{Ash content determination}

Five $\mathrm{mL}$ of fermented samples were transferred into a pre-weighed porcelain crucible and weighed. The crucible was then placed into muffle furnace for $6 \mathrm{~h}$ at $600{ }^{\circ} \mathrm{C}$ to burn off all organic materials. The inorganic material does not volatilize at that temperature and is called ash. The furnace was allowed to cool below $200{ }^{\circ} \mathrm{C}$ and maintained at this temperature for $20 \mathrm{~min}$. Then the crucible was placed in a desiccator with stopper top, allowed to cool and then reweighed to measure the ash content (A.O.A.C., 1995).

\section{Dry matter content}

Five grams each of the samples was obtained and placed into pre-weighed crucibles and dried in at $100{ }^{\circ} \mathrm{C}$ for $12 \mathrm{~h}$. The dried samples were weighed after cooling in a desiccator (A.O.A.C., 1984).

\section{Crude protein determination}

The Kjeldahl method which is the standard method for determining protein and other nitrogen containing compounds was used. Two grams of fermented samples were digested with sulphuric acid to decompose it and convert nitrogen to ammonium sulphate. The digestion 
was speed up by adding Kjeldahl catalyst tablets to increase the boiling point. The solution was cooled and concentrated sodium hydroxide added to make the solution alkaline and distilled into a weak acid (boric acid) containing methyl red indicator until solution turned from red to green. Following distillation, the ammonia was trapped as ammonium borate and quantified by titrating with a strong standard hydrochloric acid $(0.01 \mathrm{~N})$ until solution turned from green to wine to measure the nitrogenous content. The amount of crude protein was calculated by multiplying the \% nitrogen found by 6.25 $(\%)(C P=\%$ Nitrogen $\times 6.25)$ (A.O.A.C., 1984).

\section{Ether extract determination}

Beaker was placed in oven at $80{ }^{\circ} \mathrm{C}$ for $10 \mathrm{~min}$ and then removed and placed in a desiccator to cool. Then the two grams dried fermented sample was weighed into the fat beaker, a glass thimble full of anhydrous diethyl either was added to the beaker and placed on the butt-type extraction apparatus. Then boiled on high temperature for approximately $4 \mathrm{~h}$ by moving heat under it to volatilize the ether, then condensed and allowed to pass through the sample, extracting ether soluble materials. The extract is collected in a beaker, allowed to cool and the porous thimble removed with contents saved for crude fiber determination. Ether was distilled and collected in another container until beaker was almost dry and the remaining ether extract was then dried in oven at $80^{\circ} \mathrm{C}$ for $3 \mathrm{~min}$, cooled in the desiccator and weighed to measure the ether extract content (A.O.A.C, 1995).

\section{Determination of lactic acid, diacetyl and hydrogen peroxide production by LAB isolates}

This was achieved based on the methods described by Ogunbanwo et al. (2008); Bamidele et al. (2011). For these measurements the test organisms were grown in MRS broth for $72 \mathrm{~h}$ and centrifuged at $3000 \mathrm{~g}$ for $15 \mathrm{~min}$. Lactic acid was determined by transferring $25 \mathrm{~mL}$ of the supernatant fluid of the cell free of the test organisms into conical flasks and 3 drops of phenolphthalein were added as indicator. From a burette, $0.1 \mathrm{M} \mathrm{NaOH}$ was slowly added to the samples until a pink colour appeared. Each $\mathrm{mL}$ of $0.1 \mathrm{M} \mathrm{NaOH}$ is equivalent to $90.08 \mathrm{mg}$ of lactic acid.

For hydrogen peroxide, $20 \mathrm{~mL}$ of $0.1 \mathrm{M}$ diluted sulphuric acid was added to $25 \mathrm{~mL}$ of the supernatant fluid of the test organisms. Titration was carried out with $0.1 \mathrm{M}$ potassium permanganate. Each $\mathrm{mL}$ of $0.1 \mathrm{M}$ potassium permanganate is equivalent to $1.79 \mathrm{mg}$ of hydrogen peroxide solution and decolourization of the sample was regarded to be the end point.

Diacetyl was determined by transferring $25 \mathrm{~mL}$ of the supernatant fluid of the test organisms into conical flasks and $7.5 \mathrm{~mL}$ of hydroxylamine solution were used for the residual titration. The flasks were titrated with $0.1 \mathrm{M} \mathrm{HCl}$ to a greenish-yellow end point using bromophenol blue as indicator. The equivalence factor of $\mathrm{HCl}$ to diacetyl is 21.5 mg.

\section{Antagonistic activity of LAB metabolites against spoilage microorganisms}

Lactic acid bacteria were grown in MRS broth for $72 \mathrm{~h}$ and the broth cultures of the LAB were centrifuged at $10,000 \mathrm{rpm}$ for $30 \mathrm{~min}$ and the supernatant containing the metabolites were obtained and $100 \mu \mathrm{L}$ of the supernatant was transferred into wells $(6 \mathrm{~mm}$ diameter) bored in Muller Hinton and potato dextrose agar previously seeded with the spoilage bacteria cells and fungi spores obtained from spoilt tomato' after 'fungi spores respectively. The culture plates were incubated at $30{ }^{\circ} \mathrm{C}$ for $48 \mathrm{~h}$ and 7 days respectively and observed for zones of inhibition.

\section{Effect of heat treatment on antimicrobial activity of LAB metabolites}

One hundred milliliters of $72 \mathrm{~h}$ old cell free supernatant of the $L A B$ isolates was separately transferred into $250 \mathrm{~mL}$ Erlenmeyer flasks and placed inside a water bath set at 60,80 , and $100{ }^{\circ} \mathrm{C}$ for $30 \mathrm{~min}$ at different occasions and tested against the spoilage microorganisms using the well diffusion method of Schilinger and Lucke (1989) and zones of inhibition were determined.

\section{Shelf life study of tomato paste}

Healthy tomatoes were surface sterilized with $3 \%$ solution of sodium thiosulfate and blended to pulp. The tomato paste was boiled for $10 \mathrm{~min}$ and dispensed in $20 \mathrm{~g}$ amount separately into three pre-sterilized containers. Ten milliliters of LAB metabolites, methyl propylparaben (positive control) were added differently to the tomato paste and stored at $4{ }^{\circ} \mathrm{C}$ and $28{ }^{\circ} \mathrm{C}$ respectively (Safdar et al., 2010). Microbial load of each treatment was monitored by determining the colony forming unit (CFU/ g).

\section{Statistical analysis}

The experimental data were analyzed using Analysis of Variance (ANOVA) to determine significant difference between the means and these were expressed as mean \pm standard deviation (SD). The level of significance was set at $p \leq 0.05$. The data were analyzed using t-test and SPSS version 17.0

\section{RESULTS}

$L$. brevis and $L$. plantarum were isolated from healthy tomato sample with percentage occurrence of $45.4 \%$ and 54.6 respectively while $B$. megaterium, $B$. laterosorum, Pseudomonas syringe, Aspergillus fumigates, Fusarium solani, $F$. acuminatum and $F$. funjikuroi were isolated from the spoilt tomato sample showing percentage of occurrence of $6,8,10,13,19,21$, and 23 respectively (Table 1). 
Table 1: Percentage occurrence of microorganisms isolated from healthy and spoilt tomato samples.

\begin{tabular}{lc|lc}
\hline \multicolumn{2}{c|}{ Healthy tomatoes } & \multicolumn{2}{c}{ Spoilt tomatoes } \\
\hline Organisms & Percentage Occurrence & Organisms & Percentage Occurrence \\
\hline Lactobacillus brevis & 45.4 & Bacillus megaterium & 6 \\
Lactobacillus & 54.6 & Bacillus laterosorus & 8 \\
plantarum & Pseudomonas syringae & 10 \\
& & Aspergillus fumigatus & 13 \\
& Fusarium solani & 19 \\
& & Fusarium acuminatum & 21 \\
Total & Fusarium funjikuroi & 23 \\
& & Total & 100 \\
\hline
\end{tabular}

Table 2: Proximate and mineral composition of tomato samples.

\begin{tabular}{|c|c|c|c|c|c|c|c|c|c|}
\hline Samples & $\begin{array}{c}\text { Dry } \\
\text { matter }\end{array}$ & Moisture & Ash & $\begin{array}{c}\text { Ether } \\
\text { Extract }\end{array}$ & Protein & $\mathrm{Ca}$ & $\mathrm{Mg}$ & $\mathrm{K}$ & $\mathrm{Na}$ \\
\hline Healthy & $9.2 \pm 0.1^{\mathrm{a}}$ & $90.0 \pm 0.1^{\mathrm{a}}$ & $7.6 \pm 0.10^{a}$ & $1.5 \pm 0.1^{\mathrm{a}}$ & $5.6 \pm 0.1^{a}$ & $2.6 \pm 0.1^{\mathrm{a}}$ & $1.0 \pm 0.1^{\mathrm{a}}$ & $0.7 \pm 0.1^{\mathrm{a}}$ & $0.6 \pm 0.1^{\mathrm{a}}$ \\
\hline Spoilt & $6.4 \pm 0.2^{b}$ & $90.0 \pm 0.1^{a}$ & $7.6 \pm 0.3^{a}$ & $12.0 \pm 0.2^{b}$ & $5.1 \pm 0.2^{b}$ & $1.2 \pm 0.1^{a}$ & $0.4 \pm 0.1^{b}$ & $0.3 \pm 0.1^{a}$ & $0.2 \pm 0.2^{\mathrm{a}}$ \\
\hline
\end{tabular}

Mean values with different superscript down the column are statistically significant using t-test $(p \leq 0.05)$.

Table 3: Quantity of antimicrobial compounds produced by Lactobacillus species at $72 \mathrm{~h}$ of incubation.

\begin{tabular}{lccc}
\hline Isolates & Lactic acid $(\mathrm{g} / \mathrm{L})$ & Diacetyl $(\mathrm{g} / \mathrm{L})$ & Hydrogen perioxide $(\mathrm{g} / \mathrm{L})$ \\
\hline Lactobacillus brevis II & 2.3 & 1.8 & 2.4 \\
Lactobacillus plantarum I & 2.7 & 2.2 & 2.4 \\
Lactobacillus brevis I & 2.1 & 1.5 & 2.6 \\
Lactobacillus plantarum II & 2.7 & 1.2 & 1.6
\end{tabular}

The results of the proximate and mineral composition analyses of both fresh and spoilt tomato samples are shown in Table 2. The percentage dry matter, ether extract, protein, calcium, magnesium, potassium and sodium contents decreased from 9.2 $\pm 0.1,1.5 \pm 0.1$,

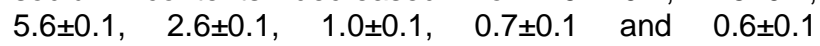
respectively in the healthy tomato sample to $6.4 \pm 0.2$, $12.0 \pm 0.2,5.1 \pm 0.2,1.2 \pm 0.1,0.4 \pm 0.1,0.3 \pm 0.1$ and $0.2 \pm 0.2$ respectively in the spoilt tomato sample.

Quantity of antimicrobial compounds produced by LAB species at $72 \mathrm{~h}$ of incubation is displayed on Table 3. All the $L A B$ species produced lactic acid, diacetyl and hydrogen peroxide. L. brevis II produced $2.3 \mathrm{~g} / \mathrm{L}$ of lactic acid, $1.8 \mathrm{~g} / \mathrm{L}$ of diacetyl and $2.4 \mathrm{~g} / \mathrm{L}$ of hydrogen perioxide while $L$. plantarum II showed a production of $2.7 \mathrm{~g} / \mathrm{L}$ lactic acid, $2.2 \mathrm{~g} / \mathrm{L}$ of diacetyl and $2.4 \mathrm{~g} / \mathrm{L}$ of hydrogen peroxide. In addition, L. brevis I recorded $2.1 \mathrm{~g} / \mathrm{L}$ of lactic acid, 1.5 $\mathrm{g} / \mathrm{L}$ and $2.6 \mathrm{~g} / \mathrm{L}$ of diacetyl and hydrogen peroxide respectively. Quantity of lactic acid, diacetyl and hydrogen peroxide produced by L. plantarum II were $2.7 \mathrm{~g} / \mathrm{L}, 1.2 \mathrm{~g} / \mathrm{L}$ and $1.6 \mathrm{~g} / \mathrm{L}$ respectively.

Table 4 represents the result of antagonistic activity of LAB metabolites against tomato spoilage organisms. $L$. brevis II inhibited $B$. megaterium, B. laterosporus, $A$. fumigatus and $F$. fujikuroi with inhibition zones of $14 \mathrm{~mm}$, $14 \mathrm{~mm}, 15 \mathrm{~mm}$ and $14 \mathrm{~mm}$ respectively but could not inhibit $P$. syringae, $F$. solani and $F$. acuminatum, but $L$. plantarum I inhibited $B$. megaterium $(18 \mathrm{~mm}), B$. laterosporus (22 mm), A. fumigatus (22 mm), F. solani (19 $\mathrm{mm}), F$. fujikuroi $(17 \mathrm{~mm}$ ) but did not inhibit $P$. syringue, and $F$. acuminatum. However $L$. plantarum II inhibited all the spoilage microorganisms with the exception of $P$. syringae and $F$. acuminatus. The metabolites of $L$. brevis I inhibited all the spoilage microorganisms with the exception of $F$. fujikuroi but $B$. megaterium, $B$. laterosporus, $P$. syringae, $A$. fumigates, $F$. solani and $F$. acuminatum were inhibited showing $10 \mathrm{~mm}, 18 \mathrm{~mm}, 12$ $\mathrm{mm}, 15 \mathrm{~mm}, 13 \mathrm{~mm}$ and $10 \mathrm{~mm}$ zones of inhibition respectively.

Table 5 represents the effect of heat treatment on LAB metabolite antagonistic property at different temperature for $30 \mathrm{~min}$ against fungal spoilage microorganisms of tomato. Metabolites of $L$. brevis inhibitory activity was only effective on A. furmigatus at 60 ${ }^{\circ} \mathrm{C}$ showing an inhibition zone of $9.0 \pm 1.00 \mathrm{~mm}$, but the metabolite was not inhibitory against all spoilage fungi at 
Table 4: Antagonistic activity of LAB metabolites against spoilage microorganisms.

\begin{tabular}{cccccccc}
\hline LAB metabolites & \multicolumn{7}{c}{ Spoilage microorganisms / Zone of Inhibition (mm) } \\
\cline { 2 - 8 } & $\begin{array}{c}B . \\
\text { megaterium }\end{array}$ & $\begin{array}{c}\text { laterosporus } \\
\end{array}$ & $\begin{array}{c}\text { syringae } \\
\text { s. }\end{array}$ & $\begin{array}{c}\text { A. } \\
\text { fumigatus }\end{array}$ & $\begin{array}{c}F . \\
\text { solani }\end{array}$ & $\begin{array}{c}F . \\
\text { acuminatum }\end{array}$ & $\begin{array}{c}\text { fujikuroi } \\
\text { ML2 }\end{array}$ \\
\cline { 2 - 8 } ML3 & 14 & 14 & - & 15 & - & - & 14 \\
ML7 & 10 & 18 & - & 22 & 19 & - & 17 \\
ML4 & 16 & 15 & - & 15 & 13 & 10 & - \\
\hline
\end{tabular}

Key: ML2 $=$ L. brevis II, ML3= L. plantarum I, ML4= L. plantarum II, ML7= L.brevis I

Table 5: Effect of heat treatment (30 min) on the antimicrobial activity of LAB metabolites against spoilage fungi.

\begin{tabular}{|c|c|c|c|c|c|c|c|c|c|c|c|c|}
\hline \multirow{3}{*}{$\begin{array}{l}\text { LAB } \\
\text { metabolites }\end{array}$} & \multicolumn{12}{|c|}{ Temperature } \\
\hline & \multicolumn{4}{|c|}{$60^{\circ} \mathrm{C}$} & \multicolumn{4}{|c|}{$80^{\circ} \mathrm{C}$} & \multicolumn{4}{|c|}{$100^{\circ} \mathrm{C}$} \\
\hline & 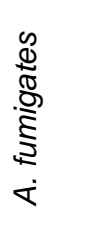 & 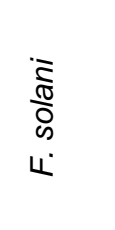 & 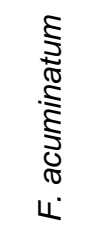 & 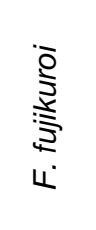 & 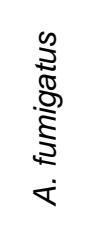 & 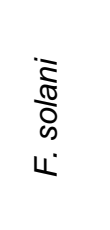 & 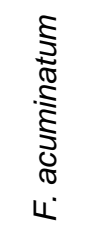 & 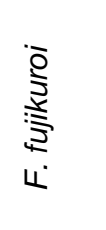 & 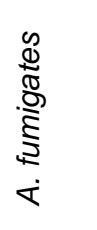 & $\begin{array}{l}\overline{\mathbf{\sigma}} \\
\frac{\mathrm{D}}{\mathrm{S}} \\
4\end{array}$ & 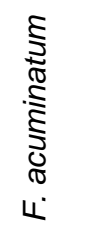 & 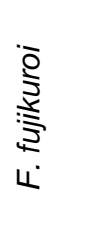 \\
\hline ML3 & $10 \pm 0.1^{c}$ & $11 \pm 0.1^{b}$ & $0 \pm 0.0^{\mathrm{a}}$ & $9 \pm 0.2^{b}$ & $9 \pm 0.2^{\mathrm{ac}}$ & $10 \pm 0.1^{d}$ & $0 \pm 0.0^{\mathrm{a}}$ & $0 \pm 0.0^{\mathrm{a}}$ & $7 \pm 0.1^{\mathrm{b}}$ & $0 \pm 0.0^{\mathrm{a}}$ & $0 \pm 0.0^{\mathrm{a}}$ & $0 \pm 0.0^{\mathrm{a}}$ \\
\hline ML2 & $9 \pm 0.1^{\mathrm{ac}}$ & $0 \pm 0.0^{a}$ & $0 \pm 0.0^{\mathrm{a}}$ & $0 \pm 0.0^{a}$ & $0 \pm 0.0^{a}$ & $0 \pm 0.0^{a}$ & $0 \pm 0.0^{a}$ & $0 \pm 0.0^{\mathrm{a}}$ & $0 \pm 0.0^{\mathrm{a}}$ & $0 \pm 0.0^{a}$ & $0 \pm 0.0^{\mathrm{a}}$ & $0 \pm 0.0^{a}$ \\
\hline ML4 & $8 \pm 0.0^{\mathrm{ab}}$ & $0 \pm 0.0^{\mathrm{a}}$ & $0 \pm 0.0^{a}$ & $0 \pm 0.0^{a}$ & $0 \pm 0.0^{\mathrm{a}}$ & $0 \pm 0.0^{a}$ & $0 \pm 0.0^{a}$ & $0 \pm 0.0^{\mathrm{a}}$ & $0 \pm 0.0^{\mathrm{a}}$ & $0 \pm 0.0^{a}$ & $0 \pm 0.0^{a}$ & $0 \pm 0.0^{a}$ \\
\hline ML7 & $9 \pm 0.0^{\mathrm{ac}}$ & $8 \pm 1.0^{c}$ & $0 \pm 0.0^{\mathrm{a}}$ & $0 \pm 0.0^{\mathrm{a}}$ & $0 \pm 0.0^{\mathrm{a}}$ & $0 \pm 0.0^{a}$ & $0 \pm 0.0^{\mathrm{a}}$ & $0 \pm 0.0^{\mathrm{a}}$ & $0 \pm 0.0^{\mathrm{a}}$ & $0 \pm 0.0^{\mathrm{a}}$ & $0 \pm 0.0^{\mathrm{a}}$ & $0 \pm 0.0^{\mathrm{a}}$ \\
\hline
\end{tabular}

Zones of Inhibition (mm) mean values with different superscript down the column are statistically significant using LSD ( $p \leq 0.05$ ).

Key: ML2, L. brevis II; ML3, L. plantarum I; ML4, L. plantarum II; ML7, L.brevis I.

$80^{\circ} \mathrm{C}$ and $100^{\circ} \mathrm{C}$. The same trend was exhibited by $L$. plantarum II, while metabolite from $L$. brevis I was inhibitory to $A$. furmigatus and $F$. solani with inhibition zones of $9.0 \pm 0.00 \mathrm{~mm}$ and $8.0 \pm 1.00 \mathrm{~mm}$ respectively at $60{ }^{\circ} \mathrm{C}$ while it could not inhibit other spoilage microorganisms at $60^{\circ} \mathrm{C}, 80^{\circ} \mathrm{C}$ and $100^{\circ} \mathrm{C}$.

Effect of heat treatment at different temperatures for $30 \mathrm{~min}$ on the antimicrobial activity of $L A B$ metabolites against spoilage bacteria is shown in Table 6 . Metabolite of ML2 at $60^{\circ} \mathrm{C}$ inhibited only $B$. lacterosporus with an inhibition zone of $12 \pm 1.00$, but did not inhibit other bacterial pathogens tested at $60^{\circ} \mathrm{C}$ and $80^{\circ} \mathrm{C}$ to $100{ }^{\circ} \mathrm{C}$ while the same metabolite inhibited $B$. lacterosporus exhibiting an inhibition zones of $13.0 \pm 1.00 \mathrm{~mm}$, at $60^{\circ} \mathrm{C}$, inhibition zone of $12 \pm 2.64 \mathrm{~mm}$ at $80{ }^{\circ} \mathrm{C}$ and inhibition zone of $5.0 \pm 1.00$ at $100{ }^{\circ} \mathrm{C}$ but did not inhibit other bacterial pathogen tested. The metabolite of ML7 only inhibited $B$. laterosponrus showing an inhibition zone $17 \pm 2.00$ at $60{ }^{\circ} \mathrm{C}$ but did not inhibit other bacterial pathogen tested at $60^{\circ} \mathrm{C}, 80^{\circ} \mathrm{C}$ and $100^{\circ} \mathrm{C}$. The same trend observed with ML4 metabolites, intuiting only $B$. laterosporus with an intubation zone of $12 \pm 1.73 \mathrm{~mm}$.

Result of the shelf life monitoring of tomato paste stored at $4{ }^{\circ} \mathrm{C}$ and $25^{\circ} \mathrm{C}$ are shown in Table 7. The control sample at stored $4{ }^{\circ} \mathrm{C}$ showed a microbial load of $2.0 \times 10^{3} \mathrm{CFU} / \mathrm{mL}$ at the tenth day while the control sample stored at $25{ }^{\circ} \mathrm{C}$ showed microbial load of $4.0 \times 10^{3}$ $\mathrm{CFU} / \mathrm{mL}$ at the fifth day. In the MP sample stored at $4{ }^{\circ} \mathrm{C}$, microbial load of $2.0 \times 10^{5} \mathrm{CFU} / \mathrm{mL}$ was detected on the $15^{\text {th }}$ day while the same sample stored at $25^{\circ} \mathrm{C}$ was observed to show a CFU/mL of $3.0 \times 10^{4}$ on $5^{\text {th }}$ day. LAB1 at $4{ }^{\circ} \mathrm{C}$ recorded $1.0 \times 10^{5} \mathrm{CFU} / \mathrm{mL}$ on the $20^{\text {th }}$ day while the same sample stored at $25^{\circ} \mathrm{C}$ showed a microbial load of $2.0 \times 10^{3}$ on $5^{\text {th }}$ day. LAB 2 recorded a microbial load of $1.0 \times 10^{3} \mathrm{CFU} / \mathrm{mL}$ on the $15^{\text {th }}$ day of storage at $4{ }^{\circ} \mathrm{C}$, while it recorded a microbial load of $3.0 \times 10^{3} \mathrm{CFU} / \mathrm{mL}$ on the $10^{\text {th }}$ day of storage at $25^{\circ} \mathrm{C}$. LAB3, when stored at 4 ${ }^{\circ} \mathrm{C}$, microbial load of $2.0 \times 10^{2} \mathrm{CFU} / \mathrm{mL}$ was detected in the sample on the $25^{\text {th }}$ day while at $25^{\circ} \mathrm{C}$ storage microbial load of $3.0 \times 10^{3} \mathrm{CFU} / \mathrm{mL}$ was observed on the $15^{\text {th }}$ day. 
Table 6: Effect of heat treatment (30 min) on the antimicrobial activity of LAB metabolites against spoilage bacteria.

\begin{tabular}{|c|c|c|c|c|c|c|c|c|c|}
\hline \multirow{3}{*}{$\begin{array}{l}\text { LAB } \\
\text { metabolites }\end{array}$} & \multicolumn{9}{|c|}{ Temperature } \\
\hline & \multicolumn{3}{|c|}{$60^{\circ} \mathrm{C}$} & \multicolumn{3}{|c|}{$80^{\circ} \mathrm{C}$} & \multicolumn{3}{|c|}{$100^{\circ} \mathrm{C}$} \\
\hline & 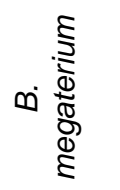 & 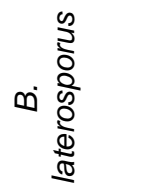 & 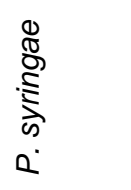 & 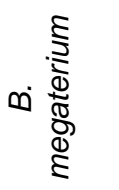 & 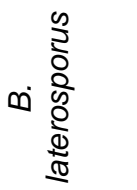 & 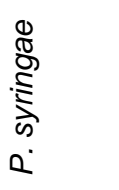 & 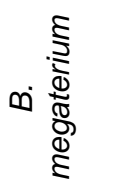 & 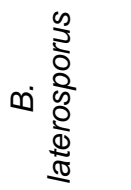 & 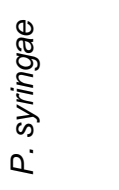 \\
\hline ML2 & $0 \pm 0.0^{a}$ & $12 \pm 0.1^{\mathrm{a}}$ & $0 \pm 0.0^{\mathrm{a}}$ & $0 \pm 0.0^{\mathrm{a}}$ & $0 \pm 0.0^{\mathrm{a}}$ & $0 \pm 0.0^{a}$ & $0 \pm 0.0^{\mathrm{a}}$ & $0 \pm 0.0^{\mathrm{a}}$ & $0 \pm 0.0^{\mathrm{a}}$ \\
\hline ML3 & $0 \pm 0.0^{a}$ & $13 \pm 0.1^{a}$ & $0 \pm 0.0^{a}$ & $0 \pm 0.0^{\mathrm{a}}$ & $12 \pm 0.3^{a}$ & $0 \pm 0.0^{a}$ & $0 \pm 0.0^{\mathrm{a}}$ & $5 \pm 0.1^{\mathrm{b}}$ & $0 \pm 0.0^{\mathrm{a}}$ \\
\hline ML7 & $0 \pm 0.0^{\mathrm{a}}$ & $17 \pm 0.2^{c}$ & $0 \pm 0.0^{a}$ & $0 \pm 0.0^{a}$ & $0 \pm 0.0^{a}$ & $0 \pm 0.0^{a}$ & $0 \pm 0.0^{a}$ & $0 \pm 0.0^{a}$ & $0 \pm 0.0^{\mathrm{a}}$ \\
\hline ML4 & $0 \pm 0.0^{a}$ & $12 \pm 0.2^{\mathrm{a}}$ & $0 \pm 0.0^{a}$ & $0 \pm 0.0^{a}$ & $0 \pm 0.0^{a}$ & $0 \pm 0.0^{\mathrm{a}}$ & $0 \pm 0.0^{a}$ & $0 \pm 0.0^{\mathrm{a}}$ & $0 \pm 0.0^{\mathrm{a}}$ \\
\hline
\end{tabular}

Zones of Inhibition $(\mathrm{mm})$ mean values with different superscript down the column are statistically significant using LSD $(p \leq 0.05)$.

Key: ML2, L. brevis II; ML3, L. plantarum I; ML4, L. plantarum II; ML7, L.brevis I.

Table 7: Shelf life monitoring of tomato paste stored at $4{ }^{\circ} \mathrm{C}$ and $25^{\circ} \mathrm{C}(\mathrm{CFU} / \mathrm{mL})$.

\begin{tabular}{|c|c|c|c|c|c|c|c|}
\hline & \multirow[t]{2}{*}{ Treatments } & \multicolumn{6}{|c|}{ Time (Days) } \\
\hline & & 1 & 5 & 10 & 15 & 20 & 25 \\
\hline \multirow{5}{*}{ 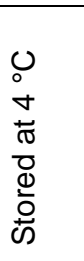 } & BT & ND & ND & $2.0 \times 10^{3}$ & $5.0 \times 10^{5}$ & $5.0 \times 10^{\prime}$ & $2.5 \times 10^{8}$ \\
\hline & MP & ND & ND & ND & $2.0 \times 10^{5}$ & $4.0 \times 10^{7}$ & $1.2 \times 10^{8}$ \\
\hline & LAB1 & ND & ND & ND & ND & $1.0 \times 10^{5}$ & $2.0 \times 10^{\prime}$ \\
\hline & LAB2 & ND & ND & ND & $1.0 \times 10^{3}$ & $3.0 \times 10^{4}$ & $2.0 \times 10^{\prime}$ \\
\hline & LAB3 & ND & ND & ND & ND & ND & $2.0 \times 10^{2}$ \\
\hline \multirow{5}{*}{ 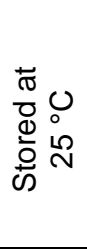 } & BT & ND & $4 \times 10^{3}$ & $1.4 \times 10^{3}$ & $2.5 \times 10^{8}$ & $5.7 \times 10^{\prime}$ & $1.05 \times 10^{8}$ \\
\hline & MP & ND & $3.0 \times 10^{4}$ & $4.0 \times 10^{5}$ & $1.5 \times 10^{5}$ & $3.2 \times 10^{\prime}$ & $6.2 \times 10^{8}$ \\
\hline & LAB1 & ND & $2.0 \times 10^{3}$ & $3.0 \times 10^{5}$ & $8.0 \times 10^{5}$ & $2.5 \times 10^{7}$ & $5.5 \times 10^{7}$ \\
\hline & LAB2 & ND & ND & $3.0 \times 10^{3}$ & $7.0 \times 10^{3}$ & $2.3 \times 10^{\prime}$ & $4.8 \times 10^{\prime}$ \\
\hline & LAB3 & ND & ND & $3.0 \times 10^{3}$ & $5.0 \times 10^{3}$ & $2.1 \times 10^{\prime}$ & $4.5 \times 10^{2}$ \\
\hline
\end{tabular}

Key: ND, not detected; BT, Control; MP, tomato + chemical preservative; LAB1, tomato + metabolite of L. plantarum 1 and $L$. brevis 1 ; LAB2, tomato + metabolite of $L$. plantarum II and $L$. brevis II; LAB3, tomato + metabolites of the four LAB.

\section{DISCUSSION}

The occurrence of $B$. megaterium, $B$. laterosporus, $P$. syringae, A. fumigatus, $F$. solani, $F$. acuminatum, and $F$. funjikuroi in spoilt tomato fruits had earlier been reported by Gosh (2009) and Ibrahim et al. (2011). This observation might be due to the ubiquitous nature of microorganisms and the ability to produce the required extra cellular enzyme to solubilise the tomato fruit into simpler components and utilize them for growth and metabolic activities (Salle, 1943; Allison et al., 2009). The isolation of species of $L A B$ from healthy tomato fruits is in accordance with findings of Sajur et al. (2007). The presence of $\angle A B$ in tomato fruit is attributed to their high survival in post harvest conditions of tomatoes (Trias et al., 2008).
The significant decrease in dry matter, ether extract, protein and mineral contents in the spoilt tomato corresponds with the report of Ibrahim et al. (2011). This might be due to microbial interaction in the spoilt tomato fruit which depleted the nutritional content of the fruit However, tomato is a perishable fruit with a high incidence of post-harvest loss (Adeoye et al., 2009) caused majorly by spoilage bacteria and fungi. In preventing these spoilage microorganisms over the years, bactericides and fungicides have been used but the accumulation of chemical residue on the produce affects the environment and consumers' health (Trias et al., 2008; Adeniyi et al., 2011).

All the LAB isolated in this work produced lactic acid, diacetyl and hydrogen peroxide to varying degrees. This observation is in accordance with the reports of Ogunbanwo et al. (2004) and the ability of LAB to 
produce antimicrobial compounds is due the absence of true catalyses to break down hydrogen peroxide generated which accumulates and becomes inhibitory to some organisms. The antagonistic activity of LAB metabolites against the spoilage bacteria and fungi agrees with the findings of Trias et al. (2008). The inhibitory effect of lactic acid is due to undissociated forms of the acids which penetrates the pathogen's membrane and liberate hydrogen ion in the neutral cytoplasm thus inhibiting vital cell functions (Corleh and Brown, 1980; Adeniyi et al., 2006). Diacetyl is known to be very effective against fungi and this is due to the interference with the utilization of arginine (De Vyust and Vandamme, 1994) and in addition to a strong oxidizing effect on the organisms cell especially bacteria (Condon, 1987).

The stability of the $\mathrm{LAB}$ metabolites at temperatures of $60^{\circ} \mathrm{C}, 80^{\circ} \mathrm{C}$ and $100^{\circ} \mathrm{C}$ revealed that as temperature increased, inhibitory activity decreased or was not detected (Assefa et al., 2008). However, Muhialdin et al. (2011) reported stability of the LAB metabolites after heat treatment for $30 \mathrm{~min}$ at $90^{\circ} \mathrm{C}$ and $121^{\circ} \mathrm{C}$.

The shelf life of tomato paste treated with LAB metabolites and stored at $4{ }^{\circ} \mathrm{C}$ showed a better preservation capability over the chemical preservative stored at $4{ }^{\circ} \mathrm{C}$. This reveals a possible potential of the LAB metabolites in the retardation of food spoilage which agrees with the findings of Ogunbanwo et al. (2008). The biopreservative potential of LAB metabolites has been tested on other food product like suya (Adesokan, et al., 2008) and chicken meat (Ogunbanwo and Okanlawon, 2006).

A major advantage in the use of lactic acid bacteria and their metabolites is that they are considered as GRAS (generally recognized as safe) and comply often with the recommendations for food products (Stiles and Holzapfel, 1997). Unlike some chemical preservatives, $\mathrm{LAB}$ metabolites have not been reported to have residual effect on the food product or the consumer's health.

\section{CONCLUSION AND RECOMMENDATION}

Lactic acid bacteria are known for the effective inhibitory activity of their metabolites against spoilage microorganisms which has been shown in other research work and in this study. Tomatoes are important, nourishing, highly perishable, widely used fruits and also serve as a source of income for producers in Nigeria. The metabolites produced by the LAB isolates in this study especially $L$. plantarum I were effective against the spoilage bacteria and fungi isolates, therefore can be used as biopreservative. Care should be taken to avoid mechanical damage in the skin of healthy tomato fruits after harvesting to prevent penetration of spoilage ENT microorganisms.

\section{ACKNOWLEDGEMENT}

The authors are grateful for the technical assistance of Mr. Jide of the Multidisciplinary Central Laboratory
(MDCL), University of Ibadan and Mr. Popoola of IART Ibadan Oyo State Nigeria.

\section{REFERENCES}

A.O.A.C. (1984). Official methods of analysis, $14^{\text {th }}$ revised edition, Association of Official Analytical Chemists. Washington. D.C. USA.

A.O.A.C. International (1995). Official Methods of Analysis of AOAC International. $16^{\text {th }}$ revised edn. Association of Official Analytical Communities. Arlington, VA, USA.

Adeniyi, B. and Iveren, D. (2011). Antifungal capacity of lactic acid bacteria isolated from salad vegetables. African Journal of Biomedical Research 14(2), 137141.

Adeniyi, B. A., Ayeni, F. A. and Ogunbanwo, S. T. (2006). Antagonistic activities of lactic acid bacteria isolated from Nigerian fermented dairy food against organisms implicated in urinary tract infection. Biotechnology 5(2), 183-188.

Adeoye, I. B., Odeleye, O. M. O., Babalola, S. O. and Afolayan, S. O. (2009). Economic analysis of tomato losses in Ibadan metropolis, Oyo state, Nigeria. African Journal of Basic and Applied Sciences 15(6), 87-92.

Adesokan, I. A., Odetoyinbo, B. B. and Olubamiwa, A. O. (2008). Biopreservative activity of lactic acid bacteria on suya produced from poultry meat. African Journal of Biotechnology 7(20), 3799-3803.

Aguirre, M. and Collins, M. D. (1993). Lactic acid bacteria and human clinical infection. Journal of Applied Bacteriology 75(2), 95-107.

Allison, S. D., LeBauer, D. S., Ofrecio, M. R., Reyes, R., Ta, A-M. and Tran, T. M. (2009). Low levels of nitrogen addition stimulate decomposition by boreal forest fungi. Soil Biology and Biochemistry 41(2), 293-302.

Alexopoulos, C. J. and Mims, C. W. (1969). Introductory mycology. $3^{\text {rd }}$ edn. J. Wiley and Sons, New York, pp. 105.

Assefa, E. Beyene, F. and Santhanam, A. (2008). Effect of temperature and $\mathrm{pH}$ on the antimicrobial activity of inhibitory substances produced by lactic acid bacteria isolated from Ergo, an Ethiopian traditional fermented milk. African Journal of Microbiology Research 2, 229-234.

Bamidele, T. A. Adeniyi, B. A. Ogunbanwo, S. T. Smith, S. I. and Omonigbehin, E. A. (2011). Antibacterial activities of lactic acid bacteria isolated from selected vegetables grown in Nigeria: A preliminary report Sierra Leone. Sierra Leone Journal of Biomedical Research 3(3), 128-132.

Bernard, O. E., Obioma, E. N. and Fabian, J. O. (1999). Growth inhibition of tomato-rot fungi by phenolic acids and essential oil extracts of pepper fruit (Dennetiatripetala). Food Research International 32, 395-399.

Buttery, R. G. (1993). Quantitative and sensory aspects of flavor of tomato and other vegetables and fruits. 
In: Flavor Science: Sensible Principles And Techniques. Acree, T. and Teranishi, R. (eds.). American Chemistry Society Books, Washington. D.C. pp. 259-286.

Clinton, S. K. (1998). Lycopene; chemistry, biology and implications for human health and diseases. Nutrition Reviews 56(2), 35-51.

Condon, S. (1987). Responses of lactic acid bacteria to oxygen. FEMS Microbiology Letters 46(3), 269-280.

Corleh, D. A. and Brown, M. H. (1980). pH and activity In: (Col) Microbial Ecology of Foods, Silkier, J. H. Academic Press, New York.

Davidson, P. M. and Harrison, M. A. (2002). Resistance and adaptation to food antimicrobials, sanitizers, and other process controls. Food Technology 56(11), 6978.

De Vuyst, L. and Vandamme, E. J. (1994). Bacteriocins of lactic acid bacteria: Microbiology, genetics and applications. Blackie Academic and Professional, London. pp. 151-221.

Fawusi, M. O. A. (1978). Emergence and seedling growth of pepper as influenced by soil compaction nutrient status and moisture regime. Society of Horticulture 9(4), 329-335.

Ghosh, A. (2009). Identification of microorganisms responsible for spoilage of tomato (Lycopersicon esculentum) fruit. Journal of Phytology 1(6), 414416.

Grubben, G. J. H. and Denton, O. A. (2004). Plant Resources of Tropical Africa 2: Vegetables. PROTA Foundation, Wageningen Netherlands/Backhuys Publissers, Leiden, Netherland/CTA, Wageningen, Netherlands pp. 668.

Ibrahim, A. D., Abubakar, A., Aliero, A. A., Sani, A. and Yakubu, S. E. (2011). Volatile metabolites profiling for discriminating tomato fruits inoculated with some bacterial pathogens. Journal of Pharmaceutical and Biomedical Sciences,1(5), 79-84.

Law Ogbomo, K. E. (2011). Comparison of growth, yield performance and profitability of tomato (Solanum lycopersicon) under different fertilizer types in humid forest ultisols. International Research Journal of Agricultural Science and Soil Science 1(8), 332-338.

Muhialdin, B. J., Hassan, Z., Sadon, S., Zulkifli, N. A. and Azfar, A. A. (2011). Effect of $\mathrm{pH}$ and heat treatment on antifungal activity of Lactobacillus fermentum te007, Lactobacillus pentosus g004 and Pediococcus pentosaceus te 010 . Innovative Romanian Food Biotechnology 8, 41-53.

Ogawa, J. M., Zehr, E. I., Bird, G. W., Ritchie, D. F., Uriu, K. and Uyemoto, J. K. (1995). Compendium of stone fruit diseases APSS press. St. Paul, Minessota pp. 57.

Ogunbanwo, S. T., Adebayo, A. A., Ayodele, M. A., Okanlawon, B. M. and Edema, M. O. (2008). Effects of lactic acid bacteria and Saccharomyces cerevisae co-culture starters on the nutritional contents and shelf life of cassava-wheat bread. Journal of Applied Biosciences 12, 612-622.
Ogunbanwo, S. T. and Okanlawon, B. M. (2006). Microbial and sensory changes during the cold storage of chicken meat treated with bacteriocin from L. brevis OG1. Pakistan Journal of Nutrition 5(6), 601-605.

Ogunbanwo, S. T., Sanni, A. I. and Onilude, A. A. (2004). Effect of bacteriocinogenic Lactobacillus spp. on the shelf life of fufu, a traditional fermented cassava product. World Journal of Microbiology and Biotechnology 20(1), 57-63.

Ogunniyi, L. T. and Oladejo, J. A. (2011). Technical efficiency of tomato production in Oyo State Nigeria. Agricultural Science Research Journal 1(4), 84-91.

Okunoya, J. A. (1996). Controlling post-harvest losses in tomatoes and pepper. Journal of Tropical Postharvest 2(1), 136-142.

Olayemi, F. F., Adegbola, J. A., Bamishaiye, E. I. and Daura, A. M. (2010). Assessment of post-harvest challenges of small scale farm holders of tomatoes, bell and hot pepper in some local government areas of Kano State, Nigeria. Bayero Journal of Pure and Applied Sciences 3(2), 39- 42.

Petro-Turza, M. (1987). Flavor of tomato and tomato products. Food Review International 2(3), 309-351.

Pla, M., Rodriguez-Lazaro, D., Badosa, E. and Montesinis, E. (2005). Measuring microbiological contamination in fruit and vegetables. In: Improving The Safety of Fresh Fruit and Vegetables. Jongen, W. (ed.). CRC Press, Abington. pp. 147-155.

Safdar, M. N., Mumtaz, A., Amjad, M., Siddiqui, N. and Hameed, T. (2010). Development and quality characteristics studies of tomato paste stored at different temperatures. Pakistan Journal of Nutrition 9(3), 265-268.

Sajur, S. A., Saguir, F. M. and Manca de Nadra, M. C. (2007). Effect of dominant species of lactic acid bacteria from tomato on the natural development in tomato puree. Food Control 18(5), 594-600.

Schillinger, U. and Lücke, F. K. (1989). Antibacterial activity of Lactobacillus sake isolated from meat. Applied Environmental Microbiology 55(8), 19011906.

Salle, A. J. (1943). Fundamental Principles of Bacteriology. McGraw-Hill book Company Inc. $2^{\text {nd }}$ edn. New York and London.

Sneath, P. H. A., Mair, N. S., Sharpe, M. E. and Holts, J. G. (1986). Bergey's Manual Systematic Bacteriology. Vol. 2. Willam and Wilkins, Baltimore.

Spadaro, D. and Gullino, M. L. (2004). State of the art and future prospects of the biological control of postharvest fruit diseases. International Journal of Food Microbiology 91(2), 185-194.

Stiles, E. M. and Holzapfel, W. H. (1997). Lactic acid bacteria of foods and their current taxonomy. International Journal of Food Microbiology 36(1), 12.

Taylor, J. H. (1987). Text of lectures delivered at the national workshop on fruit and vegetable seedlings production held at NIHORT 9-13 Technicon 
Instrument Corporation (1975). Industrial method No. 155-71.

Trias, R. Bañeras, L. Montesinos, E. and Badosa, E. (2008). Lactic acid bacteria from fresh fruit and vegetables as biocontrol agents of phytopathogenic bacteria and fungi. International Journal of Microbiology 11 (4), 231-236.

Wiessinger, W. R., Chantarapanont, W. and Beuchat, L. R. (2000). Survival and growth of Salmonella baildonin shredded lettuce and diced tomatoes, and effectiveness of chlorinated water as a sanitizer. International Journal of Food Microbiology 62 (1-2), 123-131. 